\title{
Two hybrids based on Keggin polyoxometalates and dinuclear copper(II) complexes: syntheses, structures and electrocatalytic properties
}

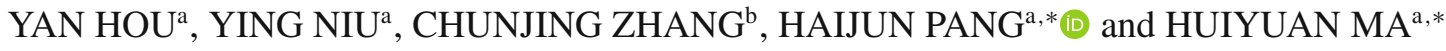 \\ ${ }^{a}$ Key Laboratory of Green Chemical Engineering and Technology of College of Heilongjiang Province, College \\ of Chemical and Environmental Engineering, Harbin University of Science and Technology, Harbin 150040, \\ People's Republic of China \\ ${ }^{\mathrm{b}}$ College of Pharmaceutical Sciences, Heilongiiang University of Chinese Medicine, Harbin 150040, People's \\ Republic of China \\ E-mail: panghj116@163.com; mahy017@163.com
}

MS received 8 June 2017; revised 12 September 2017; accepted 13 September 2017; published online 13 October 2017

\begin{abstract}
By introducing mixed-ligands en and ox, $\mathrm{Cu}^{2+}$ and different polyoxotungstates as synthons, two new polyoxotungstate-based inorganic-organic hybrid compounds $\left\{\left[\mathrm{Cu}_{2}(\mathrm{en})_{2}(\mathrm{ox})\right]\left[\mathrm{HPW}_{12} \mathrm{O}_{40}\right]\right\} \cdot(\mathrm{en})_{2} \cdot 2 \mathrm{H}_{2} \mathrm{O}$ (1) and $\left\{\left[\mathrm{Cu}_{2}(\mathrm{en})_{2}(\mathrm{ox})\right]\left[\mathrm{H}_{3} \mathrm{BW}_{12} \mathrm{O}_{40}\right]\right\} \cdot(\mathrm{en})_{2} \cdot 2 \mathrm{H}_{2} \mathrm{O}$ (2) (en = ethylenediamine and ox = oxalate), were obtained in identical hydrothermal conditions and further characterized by elemental analyses, IR spectroscopy and single-crystal X-ray diffraction. Structural analyses revealed that both compounds are isostructural, and show one-dimensional (1D) chain constructed by $\left[\mathrm{XW}_{12} \mathrm{O}_{40}\right]^{\mathrm{n}-}(\mathrm{X}=\mathrm{P} 1, \mathrm{~B} 2)$ Keggin-type polyoxoanions and $\left[\mathrm{Cu}_{2}(\mathrm{en})_{2}(\mathrm{ox})\right]^{2+}$ dinuclear copper subunits. The electrochemical experiments indicated that $\mathbf{1}$-based carbon paste electrode possesses high catalytic efficiency and selectivity towards reduction of $\mathrm{H}_{2} \mathrm{O}_{2}$, and thus $\mathbf{1}$ has potential to detect $\mathrm{H}_{2} \mathrm{O}_{2}$.
\end{abstract}

Keywords. Polyoxometalate; Keggin; dinuclear copper; electrocatalysis.

\section{Introduction}

Polyoxometalates (POMs), ${ }^{1-5}$ transition metal oxide clusters of $\mathrm{d}^{0}$ or $\mathrm{d}^{1}$ metal ions bridged via oxygen atoms, show enormous structural diversity and possess potential applications in various areas ranging across electrochemistry, ${ }^{6-11}$ catalysis, ${ }^{12-14}$ medicine ${ }^{15-18}$ and materials science. ${ }^{19-22}$ The POM-based inorganic-organic hybrids constructed from inorganic POM building blocks and various organic ligands or transition metal complex moieties can bring novel structural motifs and functionalities into one entity. ${ }^{23-29}$ In particular, the transition metal complexes (TMCs) can employ the polydentate ligands to stabilize or bridge the metal ions, provide charge compensation or form as a part of the inorganic POM framework itself and form dinuclear clusters. $^{30-32}$ Since Gutiérrez-Zorrilla and coworkers reported the first example of organic-inorganic hybrid compounds based on POMs and dinuclear copper(II) complexes in 2003, ${ }^{33}$ increasing interest has been shown in functionalization of POMs with dinuclear copper(II) complexes due to their intriguing structural features and unique properties in electrochemistry and magnetism. For instance, Gutiérrez-Zorrilla et al., have synthesized a series of compounds based on dinuclear copper(II)oxalate-bipyridine cationic complexes and copper(II)monosubstituted Keggin POMs in 2005. ${ }^{34}$ Also, Liu et $a l$., have isolated two novel organic-inorganic hybrid compounds with intriguing magnetic properties, which are constructed by Anderson-type polyoxoanions and oxalato-bridged dinuclear copper complexes. ${ }^{35}$ However, among rapidly increasing organic-inorganic hybrids, the hybrid compounds based on POMs and dinuclear copper(II)-organic complexes are still limited. The construction of hybrid compounds based on POMs

\footnotetext{
*For correspondence
}

Electronic supplementary material: The online version of this article (doi:10.1007/s12039-017-1376-1) contains supplementary material, which is available to authorized users. 
and dinuclear copper(II)-organic complexes is challenging but interesting.

As is well known, the choice of suitable ligands is crucial for the formation of the hybrid compounds based on POMs and copper(II)-organic complexes. Oxalic acid molecule generally adopts a $\mu_{2}$ coordination mode towards connecting metal cations, and thus it is a proper ligand and widely employed for construction of dinuclear copper(II)-organic complex subunits. ${ }^{36-38}$ In addition, the ethylenediamine molecule with small steric hindrance, flexible configurations and coordination modes ("Z"- and "U"-type configurations, see Figure S1 (in Supplementary Information)) is an appropriate candidate as the secondary ligand to tune the structures of final compounds.

With this strategy in mind, we chose oxalic acid and ethylenediamine mixed-ligands, Keggin clusters and $\mathrm{Cu}^{2+}$ as synthons, and tried to construct new hybrid compounds based on POMs and copper(II)organic complexes under hydrothermal condition. As expected, $\left\{\left[\mathrm{Cu}_{2}(\mathrm{en})_{2}(\mathrm{ox})\right]\left[\mathrm{HPW}_{12} \mathrm{O}_{40}\right]\right\} \cdot(\text { en })_{2} \cdot 2 \mathrm{H}_{2} \mathrm{O}$ (1) and $\left\{\left[\mathrm{Cu}_{2}(\mathrm{en})_{2}(\mathrm{ox})\right]\left[\mathrm{H}_{3} \mathrm{BW}_{12} \mathrm{O}_{40}\right]\right\} \cdot(\mathrm{en})_{2} \cdot 2 \mathrm{H}_{2} \mathrm{O}$ (2) (en $=$ ethylenediamine and ox $=$ oxalic acid anion) have been obtained. Furthermore, the electrocatalytic properties of the hybrid compounds were investigated.

\section{Experimental}

\subsection{Materials and general methods}

The chemicals used for the synthesis were obtained from commercial sources and used without further purification. These are, $\mathrm{H}_{3} \mathrm{PW}_{12} \mathrm{O}_{40} \cdot 12 \mathrm{H}_{2} \mathrm{O}$ (AR, Shanghai Zhanyun Chemical Co., Ltd, China), $\mathrm{CuCl}_{2} \cdot 2 \mathrm{H}_{2} \mathrm{O}$ (AR, Tianjin Hengxing Chemical Renfent manufacture Co., Ltd,China), oxalic acid dihydrate (AR, Tianjin Kaitong Chemical Renfent Co., Ltd, China) and ethylenediamine (AR, Tianjin Fuyu fine chemical industry Co., Ltd, China). $\mathrm{K}_{5}\left[\mathrm{BW}_{12} \mathrm{O}_{40}\right] \cdot 15 \mathrm{H}_{2} \mathrm{O}$ was synthesized according to the literature report ${ }^{39}$ and characterized by FT-IR spectrum. Elemental analyses for $\mathrm{C}, \mathrm{H}$ and $\mathrm{N}$ were performed on a Perkin-Elmer $2400 \mathrm{CHN}$ Elemental Analyzer, while analyses of $\mathrm{Cu}$ and $\mathrm{W}$ in $\mathbf{1}$ and $\mathbf{2}$ were carried out with a Leaman inductively coupled plasma (ICP) spectrometer. The FT-IR spectra were recorded using $\mathrm{KBr}$ pellets in the range of $4000-400 \mathrm{~cm}^{-1}$ with a Bruker OPTIK GmbH-Tensor II spectrometer. A CHI660 electrochemical workstation was used for the control of the electrochemical measurements and for data collection. A conventional three-electrode system was used, with a carbon paste electrode $(\mathrm{CPE})$ as a working electrode, a commercial $\mathrm{Ag} / \mathrm{AgCl}$ as reference electrode and a twisted platinum wire as counter electrode.

\subsection{Synthesis of compounds $\mathbf{1}$ and $\mathbf{2}$}

2.2.1a Synthesis of compound 1: A mixture of $\mathrm{H}_{3} \mathrm{PW}_{12} \mathrm{O}_{40}$. $12 \mathrm{H}_{2} \mathrm{O}(0.3 \mathrm{~g}, 0.1 \mathrm{mmol}), \mathrm{CuCl}_{2} \cdot 2 \mathrm{H}_{2} \mathrm{O}(0.153 \mathrm{~g}, 0.9 \mathrm{mmol})$ and oxalic acid dihydrate $(0.027 \mathrm{~g}, 3 \mathrm{mmol})$ were dissolved in $15 \mathrm{~mL} \mathrm{H}_{2} \mathrm{O}$, and then ethylenediamine $(2 \mathrm{~mL})$ was added dropwise, stirred for $1 \mathrm{~h}$ at room temperature. Subsequently, the suspension was transferred into an $18 \mathrm{~mL}$ Teflon-lined autoclave and kept under autogenous pressure at $160^{\circ} \mathrm{C}$ for 3 days with the $\mathrm{pH}$ value of the mixture was adjusted to about 5.0 with $1.0 \mathrm{~mol} \mathrm{~L}^{-1} \mathrm{NaOH}$. After slow cooling to room temperature at a rate of $10^{\circ} \mathrm{C} \cdot \mathrm{h}^{-1}$, blue block shaped crystals of 1 were obtained. The obtained crystals were washed with distilled water and dried at room temperature. The reproducibility of the compound is good in high yield.

2.2.2b Synthesis of compound 2: The synthetic procedure was similar to 1, except that the $\mathrm{K}_{5}\left[\mathrm{BW}_{12} \mathrm{O}_{40}\right] \cdot 15 \mathrm{H}_{2} \mathrm{O}(0.218 \mathrm{~g}$, $0.08 \mathrm{mmol}$ ) was used instead of $\mathrm{H}_{3} \mathrm{PW}_{12} \mathrm{O}_{40} \cdot 12 \mathrm{H}_{2} \mathrm{O}$. Blue block-shaped crystals of $\mathbf{2}$ were obtained.

2.2.3c Compound $1\left\{\left[\mathrm{Cu}_{2}(\mathrm{en})_{2}(\mathrm{ox})\right]\left[\mathrm{HPW}_{12} \mathrm{O}_{40}\right]\right\} \cdot(\mathrm{en})_{2}$. $2 \mathrm{H}_{2} \mathrm{O}$ : Yield: $36 \%$ (based on W) $\mathrm{C}_{10} \mathrm{~N}_{8} \mathrm{H}_{37} \mathrm{Cu}_{2} \mathrm{PW}_{12} \mathrm{O}_{46}$ : Anal. Found: C, 3.43; H, 1.08; N, 3.41; Cu, 3.66; W, 63.87\% Calc.: C, 3.56; H, 1.11; N, 3.33; Cu, 3.77; W, 65.47\%.

2.2.4d Compound $2\left\{\left[\mathrm{Cu}_{2}(\mathrm{en})_{2}(\mathrm{ox})\right]\left[\mathrm{H}_{3} \mathrm{BW}_{12} \mathrm{O}_{40}\right]\right\} \cdot(\mathrm{en})_{2}$. $2 \mathrm{H}_{2} \mathrm{O}$ : Yield: $42 \%$ (based on W). $\mathrm{C}_{10} \mathrm{~N}_{8} \mathrm{H}_{39} \mathrm{Cu}_{2} \mathrm{BW}_{12} \mathrm{O}_{46}$ : Anal. Found: C, 3.36; H, 1.12; N, 3.22; Cu, 3.57; W, 63.62\% Calc.: C, 3.58; H, 1.17; N, 3.34; Cu, 3.79; W, 65.82\%.

\section{$2.3 X$-ray crystallography}

The single crystal of $\mathbf{1}$ and $\mathbf{2}$ were carefully selected for single crystal X-ray diffraction analysis. Room temperature single crystal data collection for $\mathbf{1}$ and $\mathbf{2}$ were performed on a Bruker Smart Apex CCD diffractometer with Mo- $K \alpha$ radiation $(\lambda=0.71073 \AA)$ at $296 \mathrm{~K}$ and $293 \mathrm{~K}$, respectively. Multiscan absorption corrections were applied. The structures were solved by the direct method and refined by the fullmatrix least squares method on $F^{2}$ using the SHELXTL 97 crystallographic software package. ${ }^{40}$ The $\mathrm{H}$ atoms on their mother carbon and nitrogen atoms were located in calculated positions. The $\mathrm{H}$ atoms on water molecules in $\mathbf{1}$ and $\mathbf{2}$ could not be found from the residual peaks and were directly included in the final molecular formula. A summary of the crystal data, data collections and refinement parameters for $\mathbf{1}$ and $\mathbf{2}$ is listed in Table 1.

\section{Results and Discussion}

\subsection{Description of crystal structures}

Single crystal X-ray diffraction analysis reveals that both compounds $\mathbf{1}$ and $\mathbf{2}$ are isostructural and crystallize in the tetragonal, space group $I 4_{1} / a$ (No. 88). Herein, compound $\mathbf{1}$ is described as an example in detail. Compound 1 consists of $\left[\mathrm{PW}_{12} \mathrm{O}_{40}\right]^{3-}$ (abbreviated to $\mathrm{PW}_{12}$ ) 
Table 1. Crystal data and structure refinements for compounds $\mathbf{1}$ and 2.

\begin{tabular}{|c|c|c|}
\hline Empirical formula & $\mathrm{C}_{10} \mathrm{H}_{37} \mathrm{Cu}_{2} \mathrm{PW}_{12} \mathrm{~N}_{8} \mathrm{O}_{46}$ & $\mathrm{C}_{10} \mathrm{H}_{39} \mathrm{Cu}_{2} \mathrm{BW}_{12} \mathrm{~N}_{8} \mathrm{O}_{46}$ \\
\hline$M r$ & 3369.57 & 3351.43 \\
\hline Color, habit & blue, block & blue, block \\
\hline Crystal size, $\mathrm{mm}^{3}$ & $0.25 \times 0.23 \times 0.21$ & $0.25 \times 0.23 \times 0.21$ \\
\hline Crystal system & Tetragonal & Tetragonal \\
\hline Space group & $I 4_{1} / \alpha$ & $I 4_{1} / \alpha$ \\
\hline$a / \AA$ & $20.7845(5)$ & $20.703(5)$ \\
\hline$b / \AA ̊ ̊$ & $20.7845(5)$ & $20.703(5)$ \\
\hline$c / \AA$ & $23.8369(12)$ & $23.739(5)$ \\
\hline$\alpha /^{\circ}$ & 90 & 90 \\
\hline$\beta 1^{\circ}$ & 90 & 90 \\
\hline$\left.\gamma\right|^{\circ}$ & 90 & 90 \\
\hline Volume $/ \AA^{3}$ & $10297(7)$ & $10175(5)$ \\
\hline$Z$ & 8 & 8 \\
\hline$D_{\text {calcd }} / \mathrm{g} \mathrm{cm}^{-3}$ & 4.341 & 4.367 \\
\hline$\mu(\operatorname{Mo} K \alpha), \mathrm{mm}^{-1}$ & 27.639 & 27.939 \\
\hline $\mathrm{F}(000)$ & 11816.0 & 11736.0 \\
\hline$h k l$ range & $-20 \leq h \leq 27,-20 \leq k \leq 27$ & $-26 \leq h \leq 27,-27 \leq k \leq 27,-31$ \\
\hline Absorption correction & multi-scan & multi-scan \\
\hline Refl. measured/unique & $37898 / 6412$ & $37603 / 6377$ \\
\hline $\mathrm{R}_{\text {int }}$ & 0.0422 & 0.0346 \\
\hline Data/parameters & $6404 / 354$ & $6367 / 356$ \\
\hline $\mathrm{GoF}$ on $\mathrm{F}^{2}$ & 1.096 & 0.872 \\
\hline $\mathrm{R}_{1} / w \mathrm{R}_{2}[I \geq 2 \sigma(I)]^{\mathrm{a}, \mathrm{b}}$ & $0.0422 / 0.1093$ & $0.0346 / 0.1101$ \\
\hline $\mathbf{R}_{1} / w \mathbf{R}_{2}$ (all data) & $0.0592 / 0.1181$ & $0.0604 / 0.1295$ \\
\hline
\end{tabular}

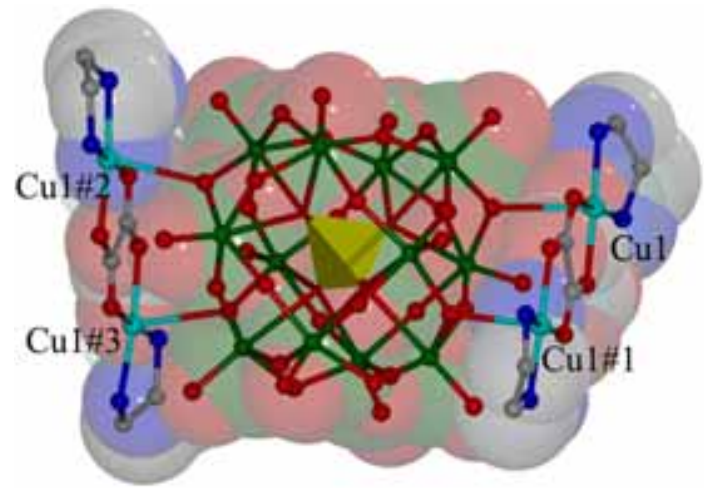

Figure 1. View of the basic crystallographic unit in $\mathbf{1}$ and the coordination mode of the $\mathrm{PW}_{12}$ cluster. All hydrogen atoms and free en and water molecules are omitted for clarity. (Symmetry code: \#1, 1-x, 1.5-y, z; \#2, 1.25-y, 0.25+x, 0.25-z; $\# 3,-0.25+\mathrm{y}, 1.25-\mathrm{x}, 0.25-\mathrm{z})$.

cluster, $\left[\mathrm{Cu}_{2}(\mathrm{en})_{2}(\mathrm{ox})\right]^{2+}$ dinuclear copper fragments, free en and water molecules (Figure 1). The $\mathrm{PW}_{12}$ cluster shows the well-known $\alpha$-Keggin type structure, ${ }^{41}$ consisting of central $\mathrm{PO}_{4}$ tetrahedron corner-sharing four triad $\left\{\mathrm{W}_{3} \mathrm{O}_{13}\right\}$ clusters. According to their different coordination environments in the polyanion, the oxygen atoms can be divided into three groups: terminal oxygen atoms $\left(\mathrm{O}_{\mathrm{t}}\right)$; bridging oxygen atoms $\left(\mathrm{O}_{\mathrm{b}}\right)$; and central oxygen atoms $\left(\mathrm{O}_{\mathrm{c}}\right)$. The average distances are $1.697 \AA, 1.912 \AA$ and $2.415 \AA$ for $\mathrm{W}-\mathrm{O}_{\mathrm{t}}, \mathrm{W}-\mathrm{O}_{\mathrm{b}}$ and $\mathrm{W}-\mathrm{O}_{\mathrm{c}}$, respectively, which are consistent with the previous reports. ${ }^{42,43}$ In the $\left[\mathrm{Cu}_{2}(\mathrm{en})_{2}(\mathrm{ox})\right]^{2+}$ dinuclear copper fragment, there is a crystallographically independent $\mathrm{Cu}$ cation ( $\mathrm{Cu} 1) . \mathrm{Cu} 1$ is six-coordinated in a near-octahedral geometry, achieved by two $\mathrm{N}$ atoms from an en molecule, two $\mathrm{O}$ atoms from an ox molecule and additional two $\mathrm{O}$ atoms from two bridge oxygen atoms of two $\mathrm{PW}_{12}$ clusters. Cu1 displays (JT) elongation axes with the JT bonds (two $\mathrm{Cu}-\mathrm{O}$ bonds) being at least $0.6 \AA$ longer than the other equatorial bonds (two $\mathrm{Cu}-\mathrm{O}$ and two $\mathrm{Cu}-\mathrm{N}$ bonds). The bond lengths around the $\mathrm{Cu} 1$ atom are in the range of 1.98-2.70 $\AA$ for $\mathrm{Cu}-\mathrm{O}$ and 1.94-1.98 $\AA$ for $\mathrm{Cu}-\mathrm{N}$, respectively.

A structural feature for $\mathbf{1}$ is its 1D chain structure constructed by $\mathrm{PW}_{12}$ anions and $\left[\mathrm{Cu}_{2}(\mathrm{en})_{2}(\mathrm{ox})\right]^{2+}$ complexes, which is described in detail as follows: Through $\mathrm{Cu}-\mathrm{O}$ bonds, each of the $\mathrm{PW}_{12}$ anions connects two neighboring $\left[\mathrm{Cu}_{2}(\mathrm{en})_{2}(\mathrm{ox})\right]^{2+}$ complexes, while each of $\left[\mathrm{Cu}_{2}(\mathrm{en})_{2}(\mathrm{ox})\right]^{2+}$ complexes links two adjacent $\mathrm{PW}_{12}$ anions. Consequently, a 1D chain is formed by repeating these connections (Figure 2). Besides, the adjacent chains are further inter-connected through hydrogen- 


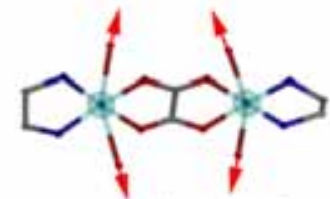

4-conected dinuclear fragment
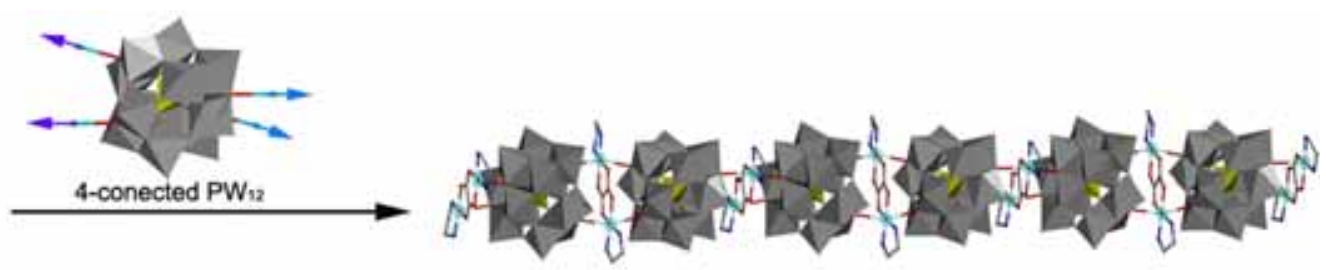

1D chain

Figure 2. View of the chain constructed by $\mathrm{PW}_{12}$ anions and $\left[\mathrm{Cu}_{2}(\mathrm{en})_{2}(\mathrm{ox})\right]^{2+}$ complexes.

bondings among the terminal/bridge oxygen atoms of $\mathrm{PW}_{12}$ anions and the hydrogen atoms of ethylenediamine molecules to generate a 3D supermolecular structure (Figure S2 in SI).

\subsection{BVS calculations and IR spectra}

All copper atoms in $\mathbf{1}$ and $\mathbf{2}$ are in the +2 oxidation state, confirmed by their octahedral coordination environments, blue crystal color and BVS calculations. ${ }^{44}$ This result is consistent with the structural analyses and charge balance. In the IR spectra (Figure S3 in SI) exhibit the characteristic peaks at $c a$. 1080, 955, 877 and $791 \mathrm{~cm}^{-1}$ in $\mathbf{1}$ as well as at $c a .1052,955,898$ and $822 \mathrm{~cm}^{-1}$ in 2 , which are attributed to $v(\mathrm{P} / \mathrm{B}-\mathrm{O})$, $v\left(W=O_{\mathrm{t}}\right), v_{a s}\left(\mathrm{~W}-\mathrm{O}_{\mathrm{b}}-\mathrm{W}\right)$ and $v_{a s}\left(\mathrm{~W}-\mathrm{O}_{\mathrm{c}}-\mathrm{W}\right)$ from $\mathrm{PW}_{12} / \mathrm{BW}_{12} \cdot{ }^{45}$ Additionally, the bands in the region of $1000-1719 \mathrm{~cm}^{-1}$ could be ascribed to the en and ox ligands, which are of low intensity with respect to those of the Keggin-type polyoxoanions. The bands at $c a$. 688, 1323 and $1662 \mathrm{~cm}^{-1}$ in $\mathbf{1}$ as well as at $c a$. 687, 1327 and $1665 \mathrm{~cm}^{-1}$ in 2 are respectively assigned to $v_{\mathrm{as}}(\mathrm{CO}), v_{\mathrm{s}}(\mathrm{CO})$ and $v(\mathrm{OCO})$ of the oxalate ligand in a bis-bidentate bridging mode. ${ }^{46,47}$

\subsection{Electrochemical properties}

It is well known that POMs possess the ability to undergo reversible multi-electron redox processes, which makes them very attractive in chemically modified electrodes and electrocatalytic studies. ${ }^{48}$ Considering that compounds $\mathbf{1}$ and $\mathbf{2}$ are isostructural, as an example, the electrocatalytic property of $\mathbf{1}$ has been investigated (please see the preparation method of the compound 1-modified carbon paste electrode in SI).

\subsection{Cyclic voltammetry $(\mathrm{CV})$}

The electrochemical behavior of a 1-modified carbon paste electrode (1-CPE) was investigated in $1 \mathrm{M} \mathrm{H}_{2} \mathrm{SO}_{4}$ aqueous solution at different scan rates (Figure 3). As shown in Figure 3, in the potential range of $-0.6 \mathrm{~V}$ to +0.8 $\mathrm{V}$, two pairs of reversible redox peaks are observed for

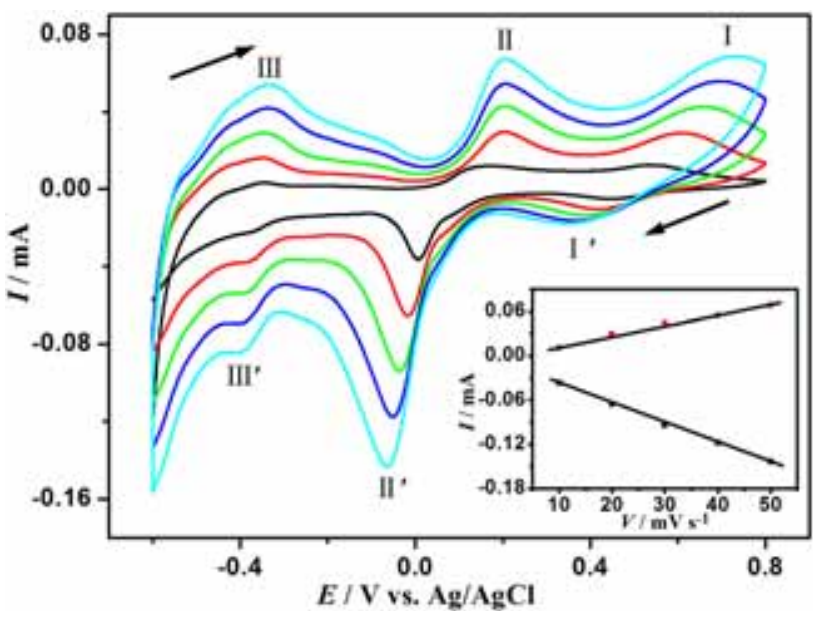

Figure 3. Cyclic voltammograms for 1-CPE in $1 \mathrm{M} \mathrm{H}_{2} \mathrm{SO}_{4}$ solution at different scan rates (from inner to outer): 10, 20, 30,40 and $50 \mathrm{mV} \cdot \mathrm{s}^{-1}$. The inset shows plots of the anodic and the cathodic peak currents for II-II' againt scan rates.

1-CPE at the scan rate $50 \mathrm{mV} \cdot \mathrm{s}^{-1}$. The mean peak potentials $E_{1 / 2}=\left(E p_{a}+E p_{c}\right) / 2$ are $0.13 \mathrm{~V}\left(\mathrm{II}-\mathrm{II}^{\prime}\right)$ and $-0.34 \mathrm{~V}$ (III-III'), which are all ascribed to two consecutive two electron processes of $\mathrm{W}^{\mathrm{VI} / \mathrm{V}}$ in the $\mathrm{PW}_{12}$ polyanion. ${ }^{49}$ In addition, there is one irreversible redox peak at 0.38 $\mathrm{V}\left(\mathrm{I}-\mathrm{I}^{\prime}\right)$, which is assigned to the redox of $\mathrm{Cu}^{\mathrm{II}} / \mathrm{Cu}^{\mathrm{I}}{ }^{50}$ As shown in the insert of Figure 3, when the scan rate is varied from 10 to $50 \mathrm{mV} \cdot \mathrm{s}^{-1}$, the peak potentials change: the cathodic peak potentials shift toward the negative direction and the corresponding anodic peak potentials to the positive direction with increasing scan rates. The peak currents are proportional to the scan rate, which indicate that the redox processes are surface controlled, ${ }^{51}$ and the exchanging rate of electrons is fast.

\subsection{Electrocatalytic activity}

The POMs have been exploited extensively in electrocatalytic reactions and further applications such as biosensors and fuel cells. ${ }^{52,53}$ Herein, the reductions of hydrogen peroxide $\left(\mathrm{H}_{2} \mathrm{O}_{2}\right)$, potassium iodate $\left(\mathrm{KIO}_{3}\right)$ and nitrite $\left(\mathrm{NaNO}_{2}\right)$ were chosen as test reactions to study the electrocatalytic activity of 1-CPE. As shown 


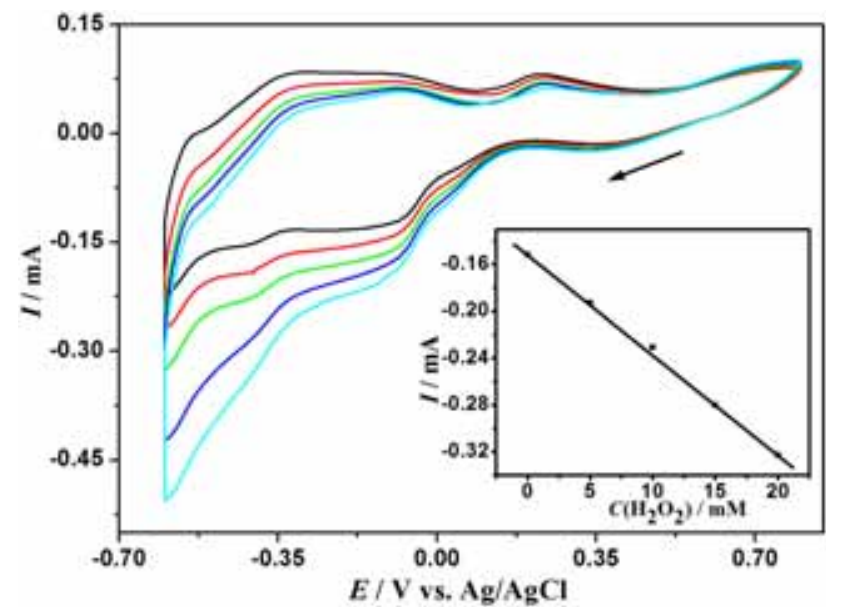

Figure 4. Electrocatalytic reduction of $\mathrm{H}_{2} \mathrm{O}_{2}$ for 1-CPE in $1 \mathrm{M} \mathrm{H}_{2} \mathrm{SO}_{4}$ solution (scan rate: $50 \mathrm{mV} \cdot \mathrm{s}^{-1}$ ) containing $\mathrm{H}_{2} \mathrm{O}_{2}$ in various concentrations (from inner to outer): $0,5,10,15$, $20 \mathrm{mM}$. The inset shows a linear dependence of the cathodic catalytic current of wave III' (see Figure 3) with $\mathrm{H}_{2} \mathrm{O}_{2}$ concentration.

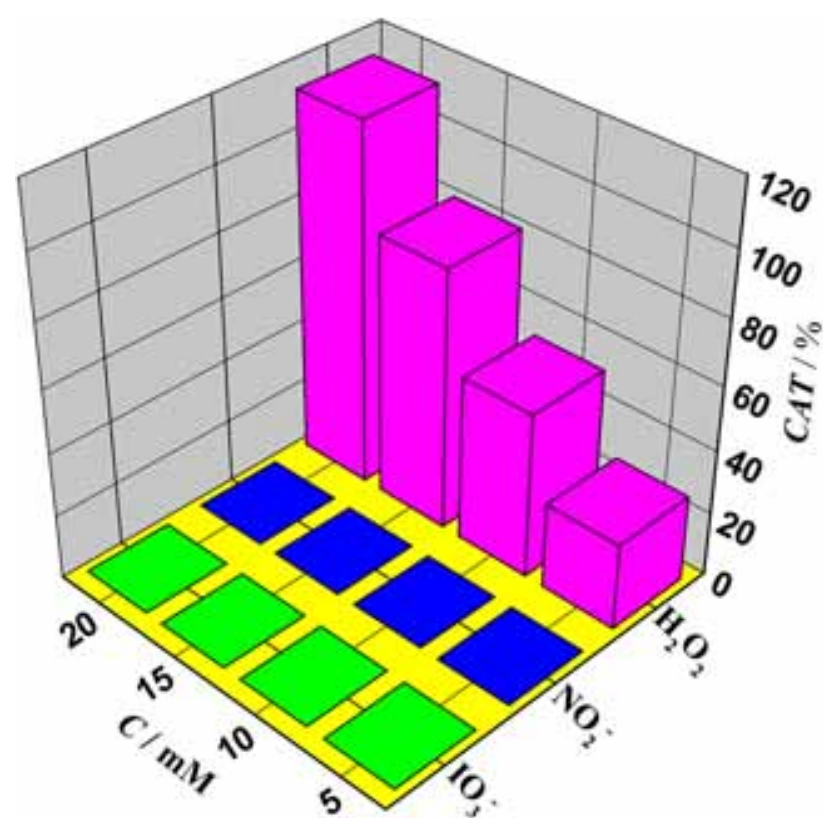

Figure 5. Chart of the CAT vs. concentration of the $\mathrm{H}_{2} \mathrm{O}_{2}$, $\mathrm{IO}_{3}^{-}$and $\mathrm{NO}_{2}^{-}$.

in Figure 4, in the potential range of -0.7 to $+0.8 \mathrm{~V}$, with addition of $\mathrm{H}_{2} \mathrm{O}_{2}$, the reduction peak currents II' and III' of 1-CPE, increase gradually while the corresponding oxidation peak currents decrease. And the nearly equal current steps for each addition of $\mathrm{H}_{2} \mathrm{O}_{2}$ demonstrate stable and efficient electrocatalytic activity of 1-CPE. On the contrary, with addition of $\mathrm{NaNO}_{2}$ and $\mathrm{KIO}_{3}$, the reduction peaks and oxidation peaks of 1-CPE are almost unaffected (Figure S4 in SI). The CAT (catalytic efficiency) of 1-CPE towards reductions of $\mathrm{NO}_{2}^{-}, \mathrm{H}_{2} \mathrm{O}_{2}$ and $\mathrm{IO}_{3}^{-}$can be evaluated using the equation below. ${ }^{54}$

$$
\begin{aligned}
\mathrm{CAT}= & 100 \% \times[\operatorname{Ip}(\mathrm{POM}, \text { substrate }) \\
& -I p(\mathrm{POM})] / I p(\mathrm{POM})
\end{aligned}
$$

where Ip (POM) and Ip (POM, substrate) are the catalytic currents of the POM in the absence and presence of substrate, respectively. As shown in Figure 5, CAT also indicates that 1-CPE possesses high catalytic efficiency and selectivity towards reductions of $\mathrm{H}_{2} \mathrm{O}_{2}$, and thus 1 has potential applications for detection of $\mathrm{H}_{2} \mathrm{O}_{2}$. Further, 1-CPE possesses higher catalytic efficiency towards reduction of $\mathrm{H}_{2} \mathrm{O}_{2}$ than most of the typical polyoxometalate-based hybrids (see the summary in Table S2 in SI). The unique structure of $\mathbf{1}$, that is the introduction of dinuclear copper(II) subunits into $\mathrm{PW}_{12}$ anions, could improve the intrinsic catalytic efficiency of polyoxometalates.

\section{Conclusions}

In summary, two new inorganic-organic hybrids based on POMs and dinuclear copper(II) complexes have been synthesized by introducing mixed-ligands en and ox, $\mathrm{Cu}^{2+}$ and different Keggin polyoxotungstates into the reaction system. The electrochemical experiments indicated that title hybrids-based carbon paste electrode possesses high catalytic efficiency and selectivity towards reduction of $\mathrm{H}_{2} \mathrm{O}_{2}$, and thus title hybrids have potential applications for the detection of $\mathrm{H}_{2} \mathrm{O}_{2}$. Also, the successful isolation of two title hybrids with intriguing structures verified that the $\mathrm{Cu}$-ox-en fragments are excellent synthons for rational design and syntheses of novel POM-based dinuclear copper(II) hybrids, which provides an effective and feasible approach to construct hybrids based on POMs and dinuclear copper(II) complexes. With hindsight, we can imagine that additional new POM-based dinuclear copper(II) hybrids could be prepared by replacement of appropriate POMs in the near future. More work in this field is underway in our laboratory.

\section{Supplementary Information (SI)}

Crystallographic data (excluding structures factors) for the structures of compounds $\mathbf{1}$ and $\mathbf{2}$ have been deposited with the Cambridge Crystallographic Data Centre bearing the CCDC Nos. 1543152 and 1543158, respectively. Copies of this information are available on request at free of charge from CCDC, Union Road, Cambridge, CB21EZ, UK (fax: +44-1223-336033; E-mail: deposit@ccdc.ac.uk or http://www.ccdc.cam. ac.uk). The "U"-type and "Z"-type coordination modes of ethylenediamine, the lengths and angles of typical hydrogenbondings (Figures S1-S4, Tables S1 and S2), preparation of 1-CPE, as well as the original data, such as IR spectra, cif (word file) and checkcif (pdf file) are available at www.ias. ac.in/chemsci. 


\section{Acknowledgements}

This work was financially supported by the NSF of China (51572063, 21371041, 21501053, 21671049), the science and technology innovation foundation of Harbin (2014RFXXJ076).

\section{References}

1. Pope M T and Müller A 1991 Polyoxometalate Chemistry: An old field with new dimensions in several disciplines Angew. Chem. Int. Ed. Engl. 3034

2. McCleverty J A and Meye T J 2004 In Comprehensive Coordination Chemistry II Vol. 1-9 (Oxford: Elsevier) p. 7861

3. Li S B, Li Z H, Zhang J Y, Su Z N, Qi S Y, Guo S H and Tan X G 2017 Polyoxometalate-based 3D porous framework with inorganic molecular nanocage units $J$. Chem. Sci. 129573

4. Arumuganathan T, Siddikha A and Das S K 2017 'Ionic crystals' consisting of trinuclear macrocations and polyoxometalate anions exhibiting single crystal to single crystal transformation: breathing of crystals J. Chem. Sci. 1291121

5. Hmida F, Ayed M, Ayed B and Haddad A 2015 Two new inorganic-organic hybrid materials based on inorganic cluster, $\left[\mathrm{X}_{2} \mathrm{Mo}_{18} \mathrm{O}_{62}\right]^{6-}(\mathrm{X}=\mathrm{P}, \mathrm{As})$ J. Chem. Sci. 127 1645

6. Sadakane M and Steckhan E 1998 Electrochemical properties of polyoxometalates as electrocatalysts Chem. Rev. 98219

7. Zhao J W, Shi D Y, Chen L J, Ma P T, Wang J P, Zhang J and Niu J Y 2013 Tetrahedral polyoxometalate nanoclusters with tetrameric rare-earth cores and germanotungstate vertexes Cryst. Growth Des. 134368

8. Guo S X, Liu Y P, Lee C Y, Bond A M, Zhang J, Geletii Y V and Hill C L 2013 Graphene-supported $\left[\left\{\mathrm{Ru}_{4} \mathrm{O}_{4}(\mathrm{OH})_{2}\left(\mathrm{H}_{2} \mathrm{O}\right)_{4}\right\}\left(\gamma-\mathrm{SiW}_{10} \mathrm{O}_{36}\right)_{2}\right]^{10-}$ for highly efficient electrocatalytic water oxidation Energy Environ. Sci. 62654

9. Thomas J, Kannan K R and Ramanan A 2008 Nanostructured phosphomolybdates J. Chem. Sci. 120529

10. Lu X X, Luo Y H, Liu Y S, Ma W W, Xu Y and Zhang H 2016 Assembly of three stable POM-based pillar-layer $\mathrm{Cu}^{\mathrm{I}}$ coordination polymers with visible light driven photocatalytic properties CrystEngComm $\mathbf{1 8} 3650$

11. Li Y W, Guo L Y, Su H F, Jagodič M, Luo M, Zhou X Q, Zeng S Y, Tung C H, Sun D and Zheng L S 2017 Two unprecedented POM-based inorganic-organic hybrids with concomitant heteropolytungstate and molybdate Inorg. Chem. 562481

12. Misono M 2001 Unique acid catalysis of heteropoly compounds (heteropolyoxometalates) in the solid state Chem. Commun. 1141

13. Hill C L 2004 Stable, self-assembling, equilibrating catalysts for green chemistry Angew. Chem. Int. Ed. 43402

14. Zhou J, Chen W C, Sun C Y, Han L, Qin C, Chen M M, Wang X L, Wang E B and Su Z M 2017 Oxidative polyoxometalates modified graphitic carbon nitride for visible-light $\mathrm{CO}_{2}$ reduction ACS Appl. Mater. Interfaces 911689
15. Rhule J T, Hill C L and Judd D A 1998 Polyoxometalates in medicine Chem. Rev. 98327

16. Shigeta S, Mori S, Kodama E, Kodama J, Takahashi $\mathrm{K}$ and Yamase T 2003 Broad spectrum anti-RNA virus activities of titanium and vanadium substituted polyoxotungstates Antivir. Res. 58265

17. Yamase T 2005 Anti-tumor, -viral, and -bacterial activities of polyoxometalates for realizing an inorganic drug J. Mater. Chem. 154773

18. Peng Q P, Li S J, Wang R Y, Liu S X, Xie L H, Zhai J X, Zhang J, Zhao Q Y and Chen X N 2017 Lanthanide derivatives of $\mathrm{Ta} / \mathrm{W}$ mixed-addendum POMs as protonconducting materials Dalton Trans. 464157

19. Coronado E and Gómez-garcía C J 1995 Polycxometalates: from magnetic clusters to molecular materials Comments Inorg. Chem. 17255

20. Mialane P, Dolbecq A, Marrot J, Rivière E and Sécheresse F 2005 A nonanuclear copper(II) polyoxometalate assembled around a $\mu$-1,1,1,3,3,3-azido ligand and its parent tetranuclear complex Chem. Eur. J. 111771

21. Mal S S and Kortz U 2005 The wheel-shaped $\mathrm{Cu}_{20}$ tungstophosphate $\left[\mathrm{Cu}_{20} \mathrm{Cl}(\mathrm{OH})_{24}\left(\mathrm{H}_{2} \mathrm{O}\right)_{12}\left(\mathrm{P}_{8} \mathrm{~W}_{48} \mathrm{O}_{184}\right)\right]^{25-}$ ion Angew. Chem. Int. Ed. 443777

22. Proust A, Thouvenot R and Gouzerh P 2008 Functionalization of polyoxometalates: towards advanced applications in catalysis and materials science Chem. Commun. 1837

23. Hagrman P J, Hagrman D and Zubieta J 1999 Organicinorganic hybrid materials: from "simple" coordination polymers to organodiamine-templated molybdenum oxides Angew. Chem. Int. Ed. 382638

24. Du D Y, Qin J S, Li S L, Su Z M and Lan Y Q 2014 Recent advances in porous polyoxometalate-based metal-organic framework materials Chem. Soc. Rev. 43 4615

25. Li F R, Lv J H, Yu K, Zhang H, Wang C M, Wang C X and Zhou B B 2017 Two extended Wells-Dawson arsenomolybdate architectures directed by $\mathrm{Na}(\mathrm{I})$ and/or $\mathrm{Cu}(\mathrm{I})$ organic complex linkers CrystEngComm 192320

26. Kikukawa Y, Kuroda Y, Yamaguchi K and Mizuno N 2012 Diamond-shaped $\left[\mathrm{Ag}_{4}\right]^{4+}$ cluster encapsulated by silicotungstate ligands: synthesis and catalysis of hydrolytic oxidation of silanes Angew. Chem. Int. Ed. 512434

27. Wang X L, Qin C, Wang E B, Li Y G, Su Z M, Xu L and Carlucci L 2005 Entangled coordination networks with inherent features of polycatenation, polythreading, and polyknotting Angew. Chem. Int. Ed. 445824

28. Niu J Y, Zhang X Q, Yang D H, Zhao J W, Ma P T, Kortz U and Wang J P 2012 Organodiphosphonatefunctionalized lanthanopolyoxomolybdate cages Chem. Eur. J. 186759

29. Ji H Y, Li X M, Xu D H, Zhou Y S, Zhang L J, Zuhra $\mathrm{Z}$ and Yang S W 2017 Synthesis, structure, and photoluminescence of color-tunable and white-light-emitting lanthanide metal-organic open frameworks composed of $\mathrm{AlMo}_{6}\left(\mathrm{OH}_{6} \mathrm{O}_{18}^{3-}\right.$ polyanion and nicotinate Inorg. Chem. 56156

30. Zapf P J, Warren C J, Haushalter R C and Zubieta J 1997 One- and two-dimensional organic-inorganic composite solidsconstructed from molybdenum oxide clusters and 
chains linked through $\mathrm{M}\left\{\left(2,2^{\prime}-\text { bpy }\right)^{2+}\right.$ fragments (M = $\mathrm{Co}, \mathrm{Ni}, \mathrm{Cu})$ Chem. Commun. 1543

31. Férey G 2001 Microporous solids: From organically templated inorganic skeletons to hybrid frameworks...ecumenism in chemistry Chem. Mater. 133084

32. Sun C Y, Liu S X, Liang D D, Shao K Z, Ren Y H and Su Z M 2009 Highly stable crystalline catalysts based on a microporous metal-organic framework and polyoxometalates J. Am. Chem. Soc. 1311883

33. Reinoso S, Vitoria P, Lezama L, Luque A and GutiérrezZorrilla J M 2003 A novel organic-inorganic hybrid based on a dinuclear copper complex supported on a Keggin polyoxometalate Inorg. Chem. 423709

34. Reinoso S, Vitoria P, Gutiérrez-Zorrilla J M, Lezama L, Felices L S and Beitia J I 2005 Inorganic-metalorganic hybrids based on copper(II)-monosubstituted Keggin polyanions and dinuclear copper(II)-oxalate complexes. Synthesis, X-ray structural characterization, and magnetic properties Inorg. Chem. 449731

35. Cao R G, Liu S X, Xie L H, Pan Y B, Cao J F, Ren Y H and Xu L 2007 Organic-inorganic hybrids constructed of Anderson-type polyoxoanions and oxalatobridged dinuclear copper complexes Inorg. Chem. 46 3541

36. Reinoso S, Vitoria P, Felices L S, Montero A, Lezama L and Gutiérrez-Zorrilla J M 2007 Tetrahydroxy- $p$ benzoquinone as a source of polydentate O-Donor ligands. synthesis, crystal structure, and magnetic properties of the $[\mathrm{Cu}(\mathrm{bpy})(\mathrm{dhmal})]_{2}$ dimer and the twodimensional $\left.\left[\mathrm{SiW}_{12} \mathrm{O}_{40} \mathrm{Cu}_{2}(\text { bpy })_{2}-\left(\mathrm{H}_{2} \mathrm{O}\right)(\mathrm{ox})\right\}_{2}\right]$. $16 \mathrm{H}_{2} \mathrm{O}$ inorganic-metalorganic hybrid Inorg. Chem. 46 1237

37. Han Q X, Ma P T, Zhao J W, Wang J P and Niu J Y 2011 A novel 1D tungstoarsenate with mixed organic ligands assembled by hexa-Cu sandwiched Keggin units and dinuclear copper-oxalate complexes Inorg. Chem. Commun. 14767

38. Zhao $\mathrm{H} \mathrm{Y}$, Zhao $\mathrm{J} \mathrm{W}$, Yang $\mathrm{B} \mathrm{F}$, He $\mathrm{H}$ and Yang G Y 2013 Novel organic-inorganic hybrid one-dimensional chain assembled by oxalate-bridging terbium-substituted phosphotungstate dimers and dinuclear copper(II)-oxalate clusters CrystEngComm $\mathbf{1 5}$ 5209

39. Deitcheff C R, Fournier M, Franck R and Thouvenot R 1983 Vibrational investigations of polyoxometalates. 2. Evidence for anion-anion interactions in molybdenum(V1) and tungsten(V1) compounds related to the Keggin structure Inorg. Chem. 22207

40. Sheldrick GM 2010 SHELXTL (version 6.1) (Madison: Bruker Analytical, X-ray Instruments Inc.)

41. Keggin J F 1993 Structure of the crystals of 12Phosphotungstic acid Nature 132351

42. Hagrman D, Hagrman P J and Zubieta J 1999 Solid-state coordination chemistry: the self-assembly of microporous organic-inorganic hybrid frameworks constructed from tetrapyridylporphyrin and bimetallic oxide chains or oxide clusters Angew. Chem. Int. Ed. 383165

43. Avarvari N and Fourmigué M 2004 1,4-Dihydro-1,4diphosphinine fused with two tetrathiafulvalenes Chem. Commun. 2794

44. Brown I D and Altermatt D 1985 Bond-valence parameters obtained from a systematic analysis of the inorganic crystal structure database Acta Crystallogr. B $\mathbf{4 1} 244$

45. Wang X L, Li N, Tian A X, Ying J, Liu G C, Lin H Y, Zhang J W and Yang Y 2013 Two polyoxometalatedirected 3D metal-organic frameworks with multinuclear silver-ptz cycle/belts as subunits Dalton Trans. 42 14856

46. Tuero L S, Garcia-lozano J, Monto E E, Borja M B, Dahan F, Tuchagues J P and Legros J P 1991 Crystal and molecular structure and magnetic properties of a new $\mu$-oxalato binuclear copper(II) complex containing mepirizole J. Chem. Soc. Dalton Trans. 2619

47. Thomas A M, Mandal G C, Tiwary S K, Rath R K and Chakravarty A R 2000 Ascorbate oxidation leading to the formation of a catalytically active oxalato bridged dicopper(II) complex as a model for dopamine $\beta$-hydroxylase J. Chem. Soc. Dalton Trans. 1395

48. Xi X D, Wang G, Liu B F and Dong S J 1995 Electrochemical behavior of Bis(2: 17-arsenotungstate) lanthanates and their electrocatalytic reduction for Nitrite Electrochim. Acta 401025

49. Fay N, Dempsey E and McCormac T 2005 Assembly, electrochemical characterisation and electrocatalytic ability of multilayer films based on $\left[\mathrm{Fe}(\mathrm{bpy})_{3}\right]^{2+}$, and the Dawson heteropolyanion, $\left[\mathrm{P}_{2} \mathrm{~W}_{18} \mathrm{O}_{62}\right]^{6-}$ J. Electroanal. Chem. 574359

50. Zhang C D, Liu S X, Sun C Y, Ma F J and Su Z M 2009 Assembly of organic-inorganic hybrid materials based on Dawson-type polyoxometalate and multinuclear copper-phen complexes with unique magnetic properties Cryst. Growth Des. 93655

51. Wang X L, Gao Q, Tian A X, Hu H L and Liu G C 2012 Effect of the Keggin anions on assembly of $\mathrm{Cu}^{I}$-bis(tetrazole) thioether complexes containing multinuclear $\mathrm{Cu}^{I}$-cluster J. Solid State Chem. 187219

52. Keita B, Oliveira P D, Nadjo L and Kortz U 2007 The ball-shaped heteropolytungstates $\left[\left\{\mathrm{Sn}\left(\mathrm{CH}_{3}\right)_{2}\left(\mathrm{H}_{2} \mathrm{O}\right)\right\}_{24}\left\{\mathrm{Sn}\left(\mathrm{CH}_{3}\right)_{2}\right\}_{12}\left(\mathrm{~A}-\mathrm{XW}_{9} \mathrm{O}_{34}\right)_{12}\right]^{36-}$ $(\mathrm{X}=\mathrm{P}, \mathrm{As})$ : stability, redox and electrocatalytic properties in aqueous media Chem. Eur. J. 135480

53. Pichon C, Mialane P, Dolbecq A, Marrot J, Riviłre E, Keita B, Nadjo L and Secheresse F 2007 Characterization and electrochemical properties of molecular icosanuclear and bidimensional hexanuclear $\mathrm{Cu}(\mathrm{II})$ azido polyoxometalates Inorg. Chem. 465292

54. Keita B, Belhouari A, Nadjo L and Contant R 1995 Electrocatalysis by polyoxometalate/vbpolymer systems: reduction of nitrite and nitric oxide J. Electroanal. Chem. 381243 